\title{
Potensi Gelatin dari Tulang Ikan sebagai Alternatif Cangkang Kapsul Berbahan Halal: Karakteristik dan Pra Formulasi
}

\author{
Lika Ginanti Febriana*,1, Nyai Ayu Sylfia Stannia P. H $^{1}$, Anisa Nur Fitriani ${ }^{1}$, Norisca Aliza Putriana²
}

${ }^{1}$ Program Studi Sarjana Farmasi, Fakultas Farmasi, Universitas Padjadjaran

2Departemen Farmasetika dan Teknologi Formulasi, Fakultas Farmasi, Universitas Padjadjaran

Sumedang, Indonesia

*Email: ginantilika@gmail.com

(Submit 25/4/2021, Revisi 25/5/2021, Diterima 12/7/2021, Terbit 15/7/2021)

\begin{abstract}
Abstrak
Gelatin merupakan produk penguraian protein hewani yang memiliki banyak fungsi di bidang pangan dan farmasi. Sebagian besar produk gelatin bersumber dari hewan, seperti babi ataupun sapi yang masih diragukan kehalalannya, baik itu yang mutlak diharamkan atau teknik penyembelihan hewan yang tidak sesuai kaidah Islam. Penggunaan gelatin sapi dan babi sebagai bahan pembuatan cangkang kapsul masih menjadi keresahan masyarakat Muslim dan Hindu. Hasil perikanan Indonesia, temasuk tulang ikan memiliki potensi besar sebagai bahan baku gelatin dalam pembuatan cangkang kapsul halal. Oleh karena itu, diperlukan pengkajian karakteristik dan praformulasi tulang ikan agar memperoleh bahan yang terstandar untuk sediaan farmasi. Metode yang digunakan dalam artikel review ini adalah dengan meninjau literatur diperoleh 32 jurnal nasional dan internasional diperoleh dari Science Direct, Research Gate dan Google Scholar sumber data dipublikasi paling lambat 10 tahun terakhir. Dari beberapa hasil penelitian terkait, dilakukan perbandingan antara parameter fisikokimia gelatin pada tulang ikan patin, ikan tuna, ikan nila, serta standar gelatin yang ditetapkan oleh GMIA (Gelatin Manufacturers Institute of America) dan SNI (Standar Nasional Indonesia). Parameter yang dibandingkan meliputi $\mathrm{pH}$, kadar air, kadar abu, kadar protein, kekuatan gel, dan viskositas. Gelatin tulang ikan berpotensi sebagai bahan dalam formulasi cangkang kapsul ditinjaukan dari sifat fisikokimianya. Gelatin tulang ikan patin memenuhi persyaratan standar gelatin GMIA dan SNI berdasarkan $\mathrm{pH}$, kadar air, kadar abu, dan viskositas, kecuali kekuatan gel dan kadar protein yang tidak memenuhi persyaratan. Sedangkan, gelatin tulang ikan tuna dan nila memenuhi seluruh parameter fisikokimia gelatin GMIA dan SNI. Dengan demikian, gelatin tulang ikan tuna dan nila berpotensi untuk dijadikan bahan dalam pembuatan cangkang kapsul untuk sediaan farmasi.
\end{abstract}

Kata kunci: Cangkang Kapsul, Gelatin, Tulang Ikan Patin, Tulang Ikan Nila, Tulang Ikan Tuna 


\section{Pendahuluan}

Gelatin adalah campuran heterogen suatu polipeptida yang diproduksi melalui proses hidrolisis kolagen yang berasal dari jaringan ikat hewan. ${ }^{1}$ Gelatin dapat diperoleh dari kulit dan tulang hewan, seperti babi, sapi, dan ikan. Pada tahun 2020, produksi gelatin secara global menghasilkan 516,8 ribu ton, sumber terbanyak berasal dari kulit babi sebesar $58 \%$ dan sisanya berasal dari kulit sapi, tulang sapi, serta sumber lainnya seperti unggas dan ikan. ${ }^{2}$ Gelatin memiliki banyak fungsi, diantaranya sebagai bahan penstabil (stabilizer), pengemulsi (emulsifier), zat pengikat, zat pengental, plastik alternatif (edible film), serta bahan matriks untuk implant. ${ }^{3}$ Pada industri makanan, gelatin terdapat pada produk marshmallow, jelly, yogurt, dan es krim. Sedangkan, pada industri farmasi gelatin digunakan pada pembuatan cangkang kapsul keras dan lunak. ${ }^{4}$ Kapsul adalah sediaan farmasi berbentuk padat yang mengandung obat di dalam cangkang keras maupun lunak yang dapat larut. Secara umum, cangkang kapsul terbuat dari gelatin atau pati. ${ }^{5}$

Penggunaan kapsul yang praktis dapat memberikan kenyamanan bagi pengguna. Kapsul dapat menutupi rasa tidak enak seperti pahit dan anyir, maupu bau yang tidak sedap. Selain itu, cangkang kapsul dapat menjaga stabilitas bahan aktif yang dapat dipengaruhi oleh. Cangkang kapsul dapat mewadahi berbagai bentuk obat mulai dari serbuk, granula, cair, dan semi padat. ${ }^{6}$ Kapsul terdiri dari dua macam, yaitu kapsul cangkang keras dan kapsul cangkang lunak. Secara umum bahan utama kedua jenis cangkang kapsul ini adalah gelatin air dan pewarna. Selain dari gelatin kapsul dapat terbuat dari dari PVA, pati (starch) dan hidroksipropil metilselulosa (HPMC). ${ }^{7}$ Cangkang kapsul keras (hard capsule) memiliki wadah dan tutup yang terbuat dari campuran gelatin, gula, dan air yang jernih dan tidak berasa. Secara umum, cangkang kapsul diisi dengan serbuk padat maupun granul. Variasi ukuran kapsul tersedia dalam ukuran besar hingga kecil diantaranya 000, 00, 1, 2, 3, 4, 5. Cangkang kapsul lunak (soft capsule) dibuat dari gelatin, agar lebih elastis ditambahkan bahan lain seperti gliserin atau alkohol polivalen dan sorbitol. Kapsul memiliki bentuk membujur seperti elips atau seperti bola dan dapat diisi dengan cairan, suspensi, bahan berbentuk pasta atau serbuk kering. ${ }^{8}$

Sediaan cangkang kapsul baik keras maupun lunak saat ini, masih memiliki masalah dalam status halal karena gelatin yang digunakan dapat berasal dari babi. Penggunaan gelatin sapi dalam produksi cangkang kapsul masih menyebabkan kekhawatiran masyarakat terkait isu penyakit sapi gila (mad cow disease) dan dilarang dikonsumsi masyarakat beragama Hindu ${ }^{9}$. Selain itu, bahan sapi dan babi memiliki harga yang lebih mahal, sehingga diperlukan bahan gelatin alternatif untuk pembuatan cangkang kapsul. Gelatin dapat bersumber dari hasil hidrolisis kolagen, yaitu protein utama yang terdapat pada daging, kulit, atau tulang hewan, salah satu nya adalah tulang ikan. Pemanfaatan tulang ikan dinilai lebih ekonomis dan mengurangi limbah yang tidak dimanfaatkan dengan baik. Namun, gelatin yang digunakan sebagai bahan farmasi seperti cangkang kapsul perlu dilakukan standarisasi. Berdasarkan hal tersebut, penelitian ini memaparkan potensi gelatin dari tulang ikan secara fisikokimia untuk pembuatan cangkang kapsul. 


\section{Metode}

Metode yang digunakan dalam artikel review ini adalah dengan meninjau literatur yang meliputi peninjauan data, pengumpulan hasil penelitian terkait yang telah dipublikasikan, dan menganalisis data yang telah dipilih seksama. Literatur yang digunakan sebagai sumber data ilmiah adalah artikel dengan rentang tahun publikasi 2012 - 2021 dengan menggunakan kata kunci "Gelatin dari Ikan Tulang Ikan", "Gelatin from Fish Bone", "Cangkang Kapsul dari Gelatin Tulang Ikan", "Karakteristik Fisikokimia gelatin tulang", "Physicochemistry Characteristics of Gelatin from Fish Bone" dari basis data Science Direct, Research Gate dan Google Scholar. Diperoleh 32 jurnal yang termasuk kedalam kriteria inklusi.

\section{Hasil dan Pembahasan}

Gelatin berbentuk serbuk atau lembaran yang tidak berasa dan tidak berbau dengan tampilan tidak berwarna atau agak kuning. Larut dalam pelarut polar seperti air panas, gliserol, dan asam asetat, tetapi tidak larut dalam pelarut organik seperti alkohol. Salah satu sumber gelatin yang melimpah adalah ikan. Sebanyak $50-70 \%$ bobot ikan adalah sisik dan tulang ikan. ${ }^{10,11}$ Indonesia memiliki hasil perikanan yang melimpah, namun pemanfaatan limbah tulang ikan belum optimal. Tulang ikan berpotensi digunakan untuk menghasilkan gelatin yang dapat digunakan dalam pembuatan cangkang kapsul.

Tabel 1. Jenis Tulang Ikan yang Berpotensi menjadi Sumber Gelatin Halal

\begin{tabular}{|c|c|c|}
\hline Judul & Sumber Gelatin & Referensi \\
\hline $\begin{array}{l}\text { Karakteristik Fisik dan Kimia Gelatin dari Tulang } \\
\text { Ikan Patin dengan Pretreatment Asam Sitrat }\end{array}$ & Tulang Ikan Patin & [12] \\
\hline $\begin{array}{c}\text { Karakteristik Gelatin Tulang Ikan Tuna Dengan } \\
\text { Perendaman Cuka Lontar Dari Nusa Tenggara } \\
\text { Timur }\end{array}$ & Tulang Ikan Tuna & [13] \\
\hline $\begin{array}{l}\text { Pengaruh Konsentrasi Asam Klorida dan Lama } \\
\text { Perendaman Terhadap Sifat Fisik dan Kimia } \\
\text { Gelatin Tulang Ikan Tuna (Thunnus albacare) }\end{array}$ & Tulang Ikan Tuna & [14] \\
\hline $\begin{array}{l}\text { Karakteristik Cangkang Kapsul yang Terbuat Dari } \\
\text { Gelatin Tulang Ikan. Jurnal Akuatika Indonesia }\end{array}$ & Tulang Ikan Nila & [15] \\
\hline $\begin{array}{c}\text { Karakteristik Gelatin Tulang Ikan Nila dengan } \\
\text { Hidrolisis Menggunakan Asam Fosfat dan Enzim } \\
\text { Papain }\end{array}$ & Tulang Ikan Nila & [16] \\
\hline $\begin{array}{l}\text { Pengaruh Lama Perendaman NaOH Pada } \\
\text { Proses Penghilangan Lemak Terhadap Kualitas } \\
\text { Gelatin Tulang Ikan Nila (Oreochromis Niloticus) }\end{array}$ & Tulang Ikan Nila & [17] \\
\hline
\end{tabular}


Gelatin pada tulang ikan diperoleh melalui ekstraksi dengan pelarut yang sesuai. Berdasarkan literatur yang diperoleh analisis parameter fisikokimia gelatin tulang ikan. Parameter-parameter fisikokimia tersebut kemudian dibandingkan dengan standar SNI atau GMIA untuk memperoleh gelatin yang sesuai persyaratan cangkang kapsul. Berikut adalah beberapa hasil penelitian gelatin dari tulang ikan patin, tuna, dan nila.

Tabel 2. Hasil Penelitian dari Gelatin Ikan Patin, Tuna, dan Nila berdasarkan Sifat Fisikokimianya dan Perbandingan dengan Standar Gelatin (GMIA dan SNI)

\begin{tabular}{|c|c|c|c|c|c|c|}
\hline No & Parameter & $\begin{array}{c}\text { Gelatin } \\
\text { Ikan } \\
\text { Patin }^{12}\end{array}$ & $\begin{array}{c}\text { Gelatin Ikan } \\
\text { Tuna }^{13,14}\end{array}$ & $\begin{array}{c}\text { Gelatin Ikan } \\
\text { Nila }^{15,16,17}\end{array}$ & GMIA $^{1}$ & SNI ${ }^{18}$ \\
\hline 1. & $\mathrm{pH}$ & 4,46 & $3,73-5,33$ & 5,83 & $4,5-6,5$ & $3,8-6,0$ \\
\hline 2. & $\begin{array}{c}\text { Kadar Air } \\
(\%)\end{array}$ & $\begin{array}{c}7,72 \\
\pm 0,01\end{array}$ & 11,85 & $9,30 \pm 0,33$ & - & $\begin{array}{c}\text { Tidak } \\
\text { melebihi } 16\end{array}$ \\
\hline 3. & $\begin{array}{c}\text { Kadar Abu } \\
(\%)\end{array}$ & $\begin{array}{r}0,38 \\
\pm 0,08\end{array}$ & 8,12 & 2,09 & - & $\begin{array}{c}\text { Tidak } \\
\text { melebihi } \\
3,25\end{array}$ \\
\hline 4. & $\begin{array}{c}\text { Kadar } \\
\text { Protein (\%) }\end{array}$ & $\begin{array}{l}58,70 \\
\pm 0,01\end{array}$ & 80,90 & 79,73-87,39 & - & $84-90$ \\
\hline 5. & $\begin{array}{c}\text { Kekuatan } \\
\text { Gel (gram } \\
\text { Bloom) }\end{array}$ & $\begin{array}{c}364,19 \\
\pm 0,04\end{array}$ & $120,37 \pm 0,9$ & $78,12-86,47$ & $150-300$ & $75-250$ \\
\hline $6 .$. & $\begin{array}{l}\text { Viskositas } \\
\text { (cP) }\end{array}$ & $\begin{array}{c}3,83 \\
\pm 0,08\end{array}$ & $4,75 \pm 0,06$ & $4,13 \pm 3,95$ & $2,5-4,5$ & $2,5-5,5$ \\
\hline
\end{tabular}

Parameter fisikokimia yang mempengaruhi kualitas gelatin diantaranya parameter $\mathrm{pH}$, kadar air, kadar abu, kadar protein, kekuatan gel, dan viskositas. Parameter-parameter tersebut juga perlu dibandingkan dengan standar gelatin farmasi kapsul berdasarkan SNI 06- 3735-1995 atau standar internasional gelatin GMIA.

\section{pH}

Gelatin memiliki sifat asam (karboksil) dan basa (amino dan guanidin). Gugus asam amino pada gelatin memberikan karakteristik amfoter karena gugus fungsi asam amino, amino terminal dan gugus karboksil dibentuk selama hidrolisis larutan asam kuat, gelatin bermuatan positif dan bermigrasi sebagai kation di medan listrik. Dengan larutan alkali kuat, gelatin menjadi bermuatan negatif dan bermigrasi sebagai anion. Tidak ada migrasi yang terjadi di titik tengah ketika titik isoelektrik adalah nol. ${ }^{19}$ 
Pengukuran nilai $\mathrm{pH}$ gelatin penting dilakukan karena $\mathrm{pH}$ gelatin mempengaruhi sifat lainnya seperti viskositas dan kekuatan gel. ${ }^{20}$ Nilai kekuatan gel maksimal sedangkan viskositas minimal pada $\mathrm{pH} 5$ yang menandakan pentingnya $\mathrm{pH}$ untuk sifat reologi. $\mathrm{pH} 5$ dan $\mathrm{pH} 8$ dipilih karena peleburan dan pembentuk gel suhu gel gelatin lebih stabil dalam kisaran $\mathrm{pH}$ 5-9 karena struktur yang lebih kuat. Gel harus harus memiliki struktur yang lebih kuat ketika $\mathrm{pH}$ jauh dari isoelektrik, sedangkan bila mendekati titik isoelektrik struktur lebih lemah. ${ }^{19} \mathrm{pH}$ memengaruhi viskositas, semakin tinggi konsentrasi asam, semakin banyak maka kation asam yang terperangkap dalam ossein, sehingga $\mathrm{pH}$ akan rendah atau bersifat asam. Selanjutnnya, proses hidrolisis kolagen dilanjutkan dengan proses penguraian polimer kolagen. ${ }^{21}$ Ikatan hidrogen dengan air molekul dan gugus asam amino bebas penting untuk kekuatan gelatin. Perubahan $\mathrm{pH}$ juga dapat menaikkan dan menurunkan viskositas gelatin pada kisaran $\mathrm{pH} 6-8 .{ }^{22}$

Berdasarkan literatur hasil, gelatin ikan patin diperoleh $\mathrm{pH}$ gelatin 4,46, gelatin ikan tuna diperoleh 3,73-5,33, serta pH gelatin ikan nila adalah 5,83. Standar GMIA untuk gelatin farmasi adalah 4,5-6,5, sedangkan standar SNI sebesar 3,8-6,0. Pada ketiga penelitian gelatin ikan patin, tuna, dan nila dihasilkan $\mathrm{pH}$ yang memenuhi standar GMIA dan SNI.

\section{Kadar Air}

Kadar air didefinisikan sebagai jumlah kandungan air pada suatu bahan yang dapat dinyatakan dengan bobot basah dan bobot kering. Kadar air adalah parameter penting karena dapat menentukan penerimaan, kesegaran, pemerian, tekstur, rasa, mutu bahan, dan daya tahan bahan. Air terdapat dalam komponen intrasel atau ekstrasel suatu produk. ${ }^{23}$ Pengukuran kadar air bertujuan untuk mengetahui jumlah air yang terkandung dalam gelatin tulang ikan. Parameter kadar air penting untuk suatu produk karena kadar air dapat menentukan waktu simpan gelatin, hal ini karena air dapat menjadi media atau tempat pertumbuhan mikroba yang berperan dalam reaksi pembusukan atau penguraian bahan. ${ }^{12}$

Kadar air pada gelatin juga dipengaruhi oleh viskositas. Nilai viskositas atau kekentalan larutan gelatin memengaruhi kadar air dalam bentuk gelatin kering. Semakin kecil kadar air pada gelatin kering, maka akan semakin tinggi daya ikat air gelatin untuk membentuk gel. Semakin banyak jumlah air dalam bentuk terikat dengan gelatin, larutan akan semakin kental, sehingga nilai viskositas akan semakin tinggi. ${ }^{24}$

Berdasarkan tabel 1 nilai kadar air ikan patin, tuna dan nilai memenuhi persyaratan. Kadar air gelatin ikan patin $7,72 \pm 0,01 \%$, kadar air gelatin tulang ikan tuna sebesar $11,85 \%$, dan kadar air tulang ikan nila sebesar $9,30 \pm 0,33 \%$. Nilai kadar air gelatin pada tiga tulang ikan memenuhi standar gelatin untuk sediaan cangkang kapsul berdasarkan SNI yaitu tidak melebihi $16 \%$, sedangkan GMIA tidak mencantumkan persyaratan kadar air untuk cangkang kapsul. 


\section{Kadar Abu}

Dalam suatu bahan baku selalu ada komponen organik dan anorganik. ${ }^{25}$ Komponen organik dapat hilang pada saat proses pembakaran, sedangkan komponen akan tersisa sebagai kadar abu. ${ }^{12,26}$ Penentuan kadar abu akan menunjukkan kemurnian suatu bahan. ${ }^{27}$ Kadar abu yang tinggi pada suatu bahan menggambarkan semakin banyak kandungan anorganik atau mineral yang terkandung pada bahan tersebut. Rendahnya kadar abu menunjukkan kualitas gelatin yang baik. ${ }^{25}$ Tingginya kadar abu dapat disebabkan oleh teknik dan alat penyaringan yang tidak sesuai, sebagaimana penelitian yang dilakukan sebelumnya. ${ }^{28,29}$ Pada saat pembentukan gelatin, tahap pre-treatment merupakan tahap yang berpengaruh terhadap kandungan mineral dari gelatin yang terbentuk. Karena pada tahap inilah terjadi proses demineralisasi untuk menghilangkan mineral sehingga didapat ossein. ${ }^{30}$

Lama perendaman, konsentrasi, dan jenis zat asam atau basa yang digunakan pada tahap pre-treatment ini pun dapat berpengaruh kepada proses pelepasan mineral yang terkandung dalam sampel. ${ }^{31}$ Kadar abu gelatin dapat diindikasikan sebagai kalsium. Tulang ikan pada umumnya memiliki kandungan kalsium yang cukup besar, kalsium akan bereaksi dengan asam atau basa dan membentuk ion kalsium yang larut. Tingginya kadar kalsium dalam gelatin akan mengurangi kejernihan sehingga gelatin yang dihasilkan cenderung keruh. Begitupun jika gelatin dijadikan bahan baku cangkang kapsul, maka kapsul yang dihasilkan tidak akan jernih. ${ }^{32}$

Kadar abu ketiga gelatin yang dihasilkan dari penelitian tersebut menunjukkan nilai yang bervariasi. Gelatin ikan patin dan ikan nila menunjukkan nilai masing-masing $0,38 \pm 0,08 \%$ dan $2,09 \%$ yang sudah sesuai dengan standar SNI, yaitu tidak melebihi $3,25 \%$. Sedangkan untuk gelatin ikan tuna dengan kadar abu sebesar 8,12\%, masih memiliki nilai kadar abu yang tidak sesuai dengan standar. Kadar abu melebihi batas standar SNI. Hal tersebut bisa terjadi karena proses ekstraksi yang kurang optimal, tahap demineralisasi, proses pencucian, penyaringan, atau kondisi bahan baku. 13,32,33

\section{Kadar Protein}

Gelatin merupakan produk penguraian rantai panjang protein yang disebut kolagen. Gelatin yang dihasilkan dari hidrolisis kolagen memiliki kandungan protein yang tinggi. ${ }^{34}$ Kadar protein menunjukkan jumlah protein yang terkandung pada bahan baku. ${ }^{12}$ Kadar protein gelatin dapat dipengaruhi oleh konsentrasi penggunaan asam atau basa saat proses demineralisasi dan perendaman. ${ }^{30,35}$ Semakin besar konsentrasi asam, semakin lama waktu perendaman, dan tingginya suhu yang digunakan akan menurunkan kadar protein, karena semakin banyak protein dalam bahan baku yang terhidrolisis. Karena rantai polipeptida penyusun protein akan rusak dengan adanya perubahan $\mathrm{pH}$ dan suhu yang ekstrim. ${ }^{36,37}$ Kadar protein pun dipengaruhi oleh jenis ikan yang digunakan, bagian tubuh yang digunakan, usia, habitat, dan pakan yang diberikan. ${ }^{2,30,38}$ 
Berdasarkan hasil literatur dari penelitian (Tabel 1), didapatkan dua penelitian gelatin ikan tuna dan nila yang memenuhi syarat SNI dengan nilai masing-masing $80,90 \%$ dan $79,73-87,3 \%$. Sedangkan, penelitian kandungan protein tulang ikan patin yang dilakukan oleh Pertiwi et al., (2018) dengan nilai 58,70 $\pm 0,01 \%$, tidak memenuhi standar yang ditetapkan SNI dengan rentang nilai $84-90 \%$.

\section{Kekuatan Gel}

Kekuatan gel merupakan parameter fisikokimia dari gelatin yang dapat menentukan karakteristik dari gelatin, terutama mengingat fungsi gelatin adalah sebagai pengemulsi dan agen pembentuk gel. ${ }^{27}$ Konsentrasi gelatin 6,67\% digunakan untuk melihat kekuatan gel dari suatu bahan baku gelatin. Bloom adalah satuan dari kekuatan gel. Bloom menunjukkan besarnya beban yang dibutuhkan sebagai sumber tekanan di daerah tertentu pada bagian muka sampel sejauh $4 \mathrm{~mm} .{ }^{1}$ Kekuatan gel gelatin atau bloom gel strength adalah salah satu karakteristik tekstur sebuah wujud benda dan merupakan gaya yang dibutuhkan dalam merubah bentuk tertentu. ${ }^{30}$

Faktor - faktor yang mempengaruhi kekuatan gel diantaranya bahan baku, perlakuan pertama, keadaan ekstraksi, panjang asam amino, $\mathrm{pH}$, berat molekul, asam amino pembentuk gel dan suhu. Kekuatan gel akan semakin besar dan meningkat apabila gugus asam amino penyusunnya semakin panjang. Rantai asam amino akan semakin panjang serta padat apabila jumlah kolagen terhidrolisa banyak dan kemampuan penyerapan air yang dilakukan gelatin semakin besar. ${ }^{39}$ Apabila nilai $\mathrm{pH}$ sangat rendah maka kekuatan gel semakin kecil, karena terjadi hidrolisis lanjutan pada untai protein yang digunakan. ${ }^{24}$

Penguraian untai polipeptida semakin banyak terjadi pada suhu tinggi. Keadaan ini terjadi karena rantai peptida menjadi pendek akibat dari hidrolisis gelatin yang menyebabkan menurunnya kekuatan gel. Selain itu suhu yang tinggi $\left(>75^{\circ} \mathrm{C}\right)$ akan menyebabkan gel rusak terdenaturasi dan akibatnya kekuatan gel rusak. ${ }^{40}$ Berat molekul yang besar menunjukkan asam amino penyusun rantai peptida berjumlah banyak dan berukuran besar sehingga penyusun rantai peptida akan menjadi lebih panjang. Semakin besar berat molekul gelatin maka kekuatan gel akan semakin besar. Glisin, prolin dan hidroksiprolin adalah asam amino penting yang mempengaruhi terbentuknya gel. Gelatin adalah polimer linier tersusun atas susunan 19 asam amino penting yang saling terikat dengan ikatan peptida. Susunan dari asam amino penting tersebut dapat berupa glisin-prolin, glisin-prolin-hidroksiprolin yang akan terus berulang. ${ }^{24}$

Berdasarkan hasil literatur dari ketiga penelitian (Tabel 1), didapatkan dua penelitian yaitu Masrukan et.al., (2018), dan Otto et al., (2015) yang memenuhi syarat SNI dengan nilai viskositas masing-masing $120,37 \pm 0,9$ dan 78,12 - 86,47. Sedangkan pada penelitian Pertiwi et al., (2018) didapatkan kekuatan gel sebesar 364,19 $\pm 0,04$ gBloom. Nilai kekuatan gel pada penelitian Pertiwi et al., (2018) terbilang tinggi hal ini dikarenakan sampel diuji setelah melalui rangkaian prosedur pemekatan gel. 
Persyaratan SNI untuk rentang nilai viskositas adalah 75 - 250 gBloom sedangkan persyaratan GMIA dengan rentang nilai 150 - 300 gBloom. Dari ketiga penelitian tersebut hanya penelitian dari Otto et al., (2015) saja yang memenuhi persyaratan dari GMIA.

\section{Viskositas}

Viskositas sangat berkorelasi dengan parameter yang dijelaskan sebelumnya yaitu kekuatan gel dan memiliki peran yang penting. ${ }^{38}$ Viskositas atau dapat disebut juga kekentalan didefinisikan sebagai kekuatan suatu cairan untuk berusaha tidak mengalir. Viskositas mempengaruhi terjadinya proses aliran suatu zat cair dibantu dengan adanya adsorbsi. ${ }^{27}$ Tujuan dilakukannya viskositas adalah untuk melihat kekentalan gelatin dalam bentuk larutan pada suhu dan konsentrasi yang ditentukan. ${ }^{39}$

Faktor-faktor yang mempengaruhi nilai viskositas adalah suhu, $\mathrm{pH}$ dan konsentrasi gelatin. Pada suhu yang tinggi sekitar lebih dari $40^{\circ} \mathrm{C}$ akan menyebabkan nilai viskositas menurun. ${ }^{10}$ Rantai asam amino akan terputus beriringan dengan konsentrasi gelatin yang meningkat, hal ini akan menyebabkan viskositas menurun. ${ }^{41}$ Asam akan berpenetrasi kuat pada saat konsentrasi asam yang digunakan tinggi dan menyebabkan ikatan kovalen antar asam amino terputus. Hal ini menghasilkan BM yang lebih rendah dengan rantai pendek sehingga viskositasnya bernilai rendah. ${ }^{42}$

Waktu perendaman yang semakin lama menyebabkan rendahnya nilai viskositas yang didapatkan, hal ini disebabkan putusnya rantai asam amino dari gelatin dan menyebabkan rantai menjadi lebih pendek. Nilai viskositas yang kurang baik dipengaruhi oleh struktur gelatin yang dimiliki oleh tulang ikan. Struktur gelatin mudah terdegradasi oleh panas sehingga semakin lama proses pemanasan maka struktur rantai gelatin yang dihasilkan akan semakin pendek. Rantai asam amino yang semakin pendek akan menyebabkan nilai viskositas semakin rendah. ${ }^{41}$

Viskositas bergantung juga kepada metode ekstraksi dan bahan yang digunakan untuk menghidrolisis gelatin tersebut. Contohnya adalah dari metode ekstraksi dengan menggunakan microwave didapatkan nilai viskositas yang rendah. Hal ini dikarenakan prinsip kerja dari microwave itu sendiri yang menyebabkan terjadinya pergerakan acak dari partikel yang menghasilkan panas. Akibat panas tersebut menyebabkan ikatan antar atom berubah menjadi tidak kuat dan terjadilah penurunan viskositas. ${ }^{43}$ Berat molekul (BM) suatu gelatin dipengaruhi juga oleh konsentrasi larutan asam. ${ }^{10}$

Berdasarkan hasil literatur dari penelitian (Tabel 1), didapatkan bahwa tiga penelitian tersebut yaitu penelitian dari Pertiwi et al., (2018), Masrukan et.al., (2018) dan Gugun et al., (2016) semuanya memenuhi syarat SNI serta GMIA dengan nilai masing-masing $3,83 \pm 0,08 \mathrm{cP}, 4,75 \pm 0,06 \mathrm{cP}$ dan $4,13 \pm 3,95 \mathrm{cP}$. Persyaratan SNI untuk rentang nilai viskositas adalah 2,5-5,5 cP sedangkan persyaratan GMIA dengan rentang nilai 2,5 $4,5 \mathrm{cP}$. 


\section{Kesimpulan}

Berdasarkan peninjauan pustaka, gelatin ikan berpotensi sebagai bahan dalam formulasi cangkang kapsul ditinjaukan dari sifat fisikokimianya. Gelatin ikan patin memenuhi persyaratan standar gelatin GMIA dan SNI berdasarkan $\mathrm{pH}$, kadar air, kadar abu, dan viskositas. Namun, kekuatan gel dan kadar protein gelatin tulang ikan melebihi persyaratan. Sedangkan, gelatin ikan tuna dan nila memenuhi semua parameter fisikokimia gelatin GMIA dan SNI yaitu pH, kadar air, kadar abu, kadar protein, viskositas, dan kekuatan gel gelatin. Dengan demikian, gelatin ikan tuna dan nila memenuhi persyaratan fisikokimia untuk dijadikan bahan dalam pembuatan cangkang kapsul untuk sediaan farmasi.

\section{Daftar Pustaka}

1. GMIA. Gelatin Handbook. USA: Gelatin manufacturers institute of america; 2012.

2. Market Report. Global Gelatin Industry [diakses 12 April 2021]. Tersedia dari https://www.reportlinker.com/p05478473/Global-GelatinIndustry.html?utm source=GNW.

3. Santosa H, Abyor H, Guyana, NL, Handono SF. Hidrolisa kolagen dalam ceker ayam hasil perendaman dengan asam asetat pada proses pembuatan gelatin. Gema Teknologi. 2018;20(1):32-36.

4. Nhari RMHR, Ismail A, Che Man YB. 2012. Analytical methods for gelatin differentiation from bovine and porcine origins and food products. Journal of Food Science 2012;71(1).

5. Depkes RI. Farmakope indonesia Edisi V. Jakarta: Kementerian Kesehatan Rl;2014.

6. Amila S. Stabilitas kadar dan laju disolusi ketoprofen dalam sediaan kapsul gelatin dan HPMC-karagenan. Prosiding Seminar Nasional Penelitian dan PKM Sains, Teknologi dan Kesehatan;2011 Desember 13;Bandung,Indonesia.Indonesia;Universitas Islam Bandung;2011.

7. He H, Ye J, Zhang X, Huang Y, Li X, Xiao MA. Locust bean gum as hard capsule gelling agent. Carbohydr Polym. 2017;175:417-424.

8. Ansel HC. Pengantar bentuk sediaan farmasi Edisi ke-4. Jakarta: UI Press;1989.

9. Atma $Y$, Hisworo R. Gelatin extraction from the indigenous pangasius catfish bone using pineapple liquid waste. Indonesian Journal of Biotechnology. 2017;22(2):8691.

10. Ward AG, Courts A. The science and technology of gelatin. New York: Academic Press;1977.

11. Wardhani DH, Esti R, Ghozi TA, Heri C. Characteristics of demineralized gelatin from lizardfish (saurida spp.) scales using $\mathrm{NaOH}-\mathrm{NaCl}$ solution. Jurnal Bahan Alam Terbarukan. 2017;6(2):132-142.

12. Pertiwi M, Yoni A, Apon ZM, Rizkia M. Karakteristik fisik dan kimia gelatin dari tulang ikan patin dengan pretreatment asam sitrat. Jurnal Aplikasi Teknologi Pangan. 2018;7(2):83-91.

13. Istiqlaal, S. Karakteristik gelatin tulang ikan tuna dengan perendaman cuka lontar dari Nusa Tenggara Timur. JPHPI. 2018;21(3):443-450. 
14. Masrukan PY, Santoso U. Pengaruh konsentrasi asam klorida dan lama perendaman terhadap sifat fisik dan kimia gelatin tulang ikan tuna (thunnus albacare). AGOTECH. 2016;1(1):34-42.

15. Junianto, Kiki $\mathrm{H}$, Ine $\mathrm{M}$. Karakteristik cangkang kapsul yang terbuat dari gelatin tulang ikan. Jurnal Akuatika Indonesia. 2013;4(1):46-54.

16. Gugun $\mathrm{H}$, Eko ND, Laras R. Karakteristik gelatin tulang ikan nila dengan hidrolisis menggunakan asam fosfat dan enzim papain. JPHPI. 2016;19(1):69-78.

17. Otto AW, Titi S, Sumardianto. Pengaruh lama perendaman naoh pada proses penghilangan lemak terhadap kualitas gelatin tulang ikan nila (oreochromis niloticus). Jurnal Pengolahan dan Bioteknologi Hasil Perikanan. 2015;4(2):25-32.

18. BSN. Mutu dan Cara Uji Gelatin Standar Nasional Indonesia (SNI) 06-3735-1995. Jakarta: Dewan Standarisasi Nasional;1995.

19. Nurul AG, Sarbon NM. Effects of $\mathrm{pH}$ on functional, rheological and structural properties of eel (monopterus sp.) skin gelatin compared to bovine gelatin. International Food Research Journal. 2015;22(2):572-583.

20. Mardawati E, Sugandi H, Kayaputri IL, Cahyana Y, Wira DW, Pujianto T, et al. Study and characterization of powder mackerel (scomberomorus commerson) bone gelatin through hydrolysis of hydrochloric acid. AIP Conference Proceedings; 2018 Februari 9; Bandung, Indonesia. Indonesia: Universitas Padjadjaran; 2018.

21. Glicksman M. Gum technology in food industry. New York: Academic Press.1969.

22. Firlianty IR. Physico-chemical characterization and skin gelatin rheology of four freshwater fish as alternative gelatin source. AACL Bioflux. 2016;9(6):1196-1207.

23. Rosida R, Lia H, Dwi A. Pemanfaatan limbah tulang ikan kambing-kambing (abalistes stellaris) sebagai gelatin menggunakan variasi konsentrasi $\mathrm{CH} 3 \mathrm{COOH}$. Aquatic Sciences Journal. 2018;5(2):93-99.

24. Candra S, Titi S, Sumardianto. Perbedaan penggunaan konsentrasi larutan asam sitrat dalam pembuatan gelatin tulang rawan ikan pari mondol (himantura gerrardi). Jurnal Pengolahan dan Bioteknologi Hasil Perikanan. 2015;4(2):106-114.

25. Rahayu F, Fithriyah $\mathrm{NH}$. Pengaruh waktu ekstraksi terhadap rendemen gelatin dari tulang ikan nila merah. Prosiding Seminar Nasiomal Sains dan Teknologi; 2015 November 17; Jakarta, Indonesia. Indonesia: Universitas Muhammadiyah Jakarta;2015.

26. Gunawan F, Suptijah P, Uju. Ekstraksi dan karakterisasi gelatin kulit ikan tenggiri (scomberomorus commersonii) dari Provinsi Kepulauan Bangka Belitung. JPHPI. 2017;20(3):568-581.

27. Iqbal MC, Anam AA, Ridwan. Optimasi rendemen dan kekuatan gel gelatin ekstrak tulang ikan lele dumbo (clarias gariepinus sp.). Jurnal Teknosains Pangan. 2015;9(4):8-10.

28. Idiawati N, Maulida R, Arianie L. Pengaruh konsentrasi asam klorida pada ekstraksi gelatin dari ikan tulang tenggiri. Jurnal Sains dan Teknologi Kimia. 2014;5(1):1-9.

29. Puspawati NM, Simpen IN, Suciptawati NLP. Karakteristik sifat fisiko kimia gelatin halal yang diekstrak dari kulit ayam broiler melalui variasi suhu. Jurnal Kimia. 2014;8(1):127-136.

30. Suptijah P, Indriani D, Wardoyo SE. Isolasi dan karakterisasi kolagen dari kulit ikan patin (pangasius sp.). Jurnal Sains Natural Universitas Nusa Bangsa. 2018;8(1):823. 
31. Tuslinah L, Wulandari WT, Ruswanto. Isolasi dan karakterisasi gelatin dari kulit ikan lele (clarias gariepinus) dan tulang ikan gurame (osphronemus gourami, lac) sebagai limbah. Jurnal Farmasi Galenika. 2019;6(1):1-10.

32. Bhernama BG, Nasution RS, Nisa SU. Ekstraksi gelatin dari tulang ikan kakap putih (lates calcarifer) dengan variasi konsentrasi asam $\mathrm{HCl}$. Jurnal Sains Natural Universitas Nusa Bangsa. 2020;10(2):43-54.

33. Saputra $\mathrm{RH}$, Widiastuti I, Supriadi A. Karakteristik fisik dan kimia gelatin kulit ikan patin (pangasius pangasius) dengan kombinasi berbagai asam dan suhu. Jurnal Teknologi Hasil Perikanan. 2015;4(1):29-36.

34. Baehaki A, Lestari SD, Romadhoni AR. Protein hydrolysis from catfish prepared by papain enzyme and antioxidant activity of hydrolyzate. JPHPI. 2015;18(3):108-118.

35. Samosir AS, Idiawati N, Destiarti L. Ekstraksi gelatin dari kulit ikan toman (channa micropeltes) dengan variasi konsentrasi dari asam asetat. Jurnal Kimia Khatulistiwa. 2018;7(3): 104-108.

36. Pradarameswari KA, Zaelani K, Waluyo E, dan Nrdiani R. The physico-chemical properties of pangas catfish (pangasius pangasius) skin gelatin. IOP Conf Ser:Earth Environ Sci. 2017;137:1-8.

37. Rachmania RA, Nisma F, Mayangsari E. Ekstraksi gelatin dari tulang ikan tenggiri melalui proses hidrolisis menggunakan larutan basa. Media Farmasi. 2013;10(2):18-28.

38. Permata Y, Widiastri F, Sudaryanto, Anteng A. Gelatin dari tulang ikan lele (clarias batrachus): pembuatan dengan metode asam, karakterisasi dan aplikasinya sebagai thickener pada industri sirup. Jurnal IImiah Widya Teknik. 2016;15(2):146-152.

39. Yenti R, Nofiandi D, Fithriyah R. Pengaruh variasi konsentrasi asam asetat terhadap kuantitas gelatin dari kulit ikan sepat rawa (trichogaster trichopterus) kering dan karakterisasinya. Scientia. 2016;6(1):36-43.

40. Hafidz. Pembuatan gelatin halal dari tulang ikan bandeng (chanoschanos forskal) (sebagai alternatif pembuatan gelatin halal) (disertasi). Malang: UIN Malang; 2011.

41. Huda WN, Atmaka W, Nurhartadhi E. Kajian karakteristik fisik dan kimia gelatin ekstrak tulang kaki ayam, dengan variasi lama perendaman konsentrasi asam. Jurnal Teknosains Pangan. 2013;2(3):70-75.

42. Trilaksani W, Nurilmala M, Setiawati IH. Ekstraksi gelatin kulit ikan kakap merah (lutjanus sp.) hasil proses perlakuan asam (disertasi). Bogor: IPB; 2012.

43. Dewi $R$, Wardana ING, Hamidi N. Pengaruh daya penyinaran gelombang mikro terhadap karakteristik pembakaran droplet minyak jarak pagar. jurnal rekayasa mesin. 2012;3(2):305-316. 